\title{
UJI DAYA HAMBAT JAMUR ENDOFIT AKAR BAKAU Rhizophora apiculata TERHADAP BAKTERI Staphylococcus aureus dan Escherichiae coli
}

\author{
Riskah Kartika \\ Widdhi Bodhi \\ Billy Kepel \\ Robert Bara
}

\author{
Bagian Kimia Fakultas Kedokteran Universitas Sam Ratulangi \\ Email: Riskahkartika10_162@yahoo.co.id
}

\begin{abstract}
Endophytic Fungus is a microbial resources whichexist in the plant tissues and produce bioactive compounds which potentially could be developed into raw materials for drugs/medicine, such as anticancer and antibiotics. Endophytic Fungi could be found on many plants, such as Rhizophora apiculata, one of the mangroves found in Indonesia. This research aims to procure the endophytic fungal isolates from the mangrove roots Rhizophora apiculataand to test the activity of anti-bacterial of endophytic fungi on bacterium Staphylococcus aureus andEscherichiae coli. This research was done in Pharmacology Laboratory Faculty of Medicine on Sam Ratulangi University, Manado from November 2013 to January 2014. This research was an experimental research in the laboratory using the Control Trial Design. The endophytic fungi was cultured on carbohydrate-rich media, and then the bioactivity on the experimental bacterium was tested. The result of the research showed that there were two endophytic fungals isolates procured, which were black fungi and white fungi. As antibacterial activity, both of the endophytic fungi showed that there was an inhibition at the two experimental fungis. The antibacterial's activity testing of mangrove roots Rhizophora apiculataon the growth of bacterial Staphylococcus aureusandEscherichiae coliwas showing an inhibitory effect to both of the fungi. Advance study are needed.
\end{abstract}

Keyword: Antibacterial, endophytic fungi, endophytic microbes, Rhizophora apiculata

\begin{abstract}
Abstrak: Jamur endofit merupakan suatu sumber daya mikroba yang terdapat dalam jaringan tumbuhan dan memproduksi senyawa-senyawa bioaktif yang potensial untuk dikembangkan menjadi bahan baku obat, seperti antikanker dan antibiotik. Jamur endofit dapat ditemukan pada berbagai jenis tumbuhan, seperti misalnya Rhizophora apiculata, salah satu tumbuhan bakau yang banyak dijumpai di Indonesia. Penelitian ini bertujuan untuk memperoleh isolat jamur endofit dari akar bakau Rhizophora apiculata, dan menguji aktivitas antibakteri jamur endofit tersebut terhadap bakteri Staphylococcus aureus dan Escherichiae coli. Penelitian ini dilakukan di Laboratorium Farmakologi Fakultas Kedokteran Universitas Sam Ratulangi Manado Sejak bulan November 2013 hingga Januari 2014. Penelitian ini merupakan penelitian eksperimental laboratorium dengan menggunakan rancangan control trial. Secara umum, jamur endofit dikultur dalam media kaya karbohidrat, kemudian diuji bioaktivitasnya terhadap bakteri uji. Hasil penelitian menunjukkan bahwa terdapat dua isolat jamur endofit yang dihasilkan, yaitu jamur hitam dan jamur putih. Pada pengujian antibakteri, kedua jamur endofit tersebut menunjukkan adanya daya hambat pertumbuhan kedua bakteri uji. Uji aktivitas antibakteri akar bakau Rhizophora apiculata terhadap pertumbuhan bakteri Staphylococcus aureus dan Escherichiae coli memberikan efek penghambatan terhadap kedua bakteri tersebut. Perlu diadakan penelitian lebih lanjut.
\end{abstract}

Kata kunci : Antibakteri, Jamur endofit, Mikroba endofit, Rhizophora apiculata 
Jamur endofit merupakan salah satu mikroba endofit yang hidup di dalam jaringan tumbuhan dan mampu memproduksi senyawa-senyawa bioaktif yang potensial untuk dikembangkan menjadi bahan baku obat, termasuk antikanker dan antibiotika. Sebagai contoh yaitu senyawa taxol, senyawa antikanker yang dihasilkan oleh tumbuhan Taxus brevifolia. Pada tahun 1993, taxol telah diisolasi dari Taxomyces andreanae, fungi endofit yang tumbuh pada tumbuhan T. pasifica. $^{1}$

Indonesia sebagai negara kepulauan terbesar di dunia memiliki garis pantai dan luas laut yang cukup besar. Hal ini menjadikan sumber daya alam yang terkandung di dalamnya sangat melimpah. Salah satu jenis tumbuhan bakau yang sering ditemui di pesisir pantai yaitu spesies Rhizophora apiculata. ${ }^{2}$ Bakteri uji yang digunakan dalampenelitian ini merupakan flora normal yang terdapat dalam tubuh manusia, akan tetapi padakeadaan tertentu bakteri tersebut dapat berpotensimembahayakan dan menjadi patogen.Bakteri uji yang digunakanyaituEscherichia coli dan Staphylococcus aureus. ${ }^{3,4}$

Berdasarkan latar belakang dan masalah diatas, maka penelitian ini bertujuan untuk melihat daya hambat dari jamur endofit yang diambil dari akar tumbuhan Bakau Rhizophora apiculata terhadap pertumbuhan bakteri Staphylococcus aureus dan Escherichia coli yang dikultur pada media agar.

\section{METODE PENELITIAN}

Penelitian ini dilakukan di Laboratorium Farmakologi Fakultas Kedokteran Universitas Sam Ratulangi Manado sejak November 2013 hingga Januari 2014. Penelitian ini merupakan penelitian eksperimental laboratorium dengan rancangan control trial.

\section{Alat dan bahan}

Alat yang digunakan dalam penelitian ini antara lain : cawan petri, tabungreaksi, pinset, kapaslidisteril, kertassaring, oven, inkubator, apibunsen, object glass, mikroskop, jarumose, jangkasorong, sendokplastik, timbangan, tabungerlenmeyer, komporlistrik, kamera, spidol, otoklaf, sarungtangan, akar bakau Rhizophora apiculata, Potato Dekstrose Agar (PDA), Nutrient Agar (NA).

\section{SterilisasiAlat}

Alat-alat yang digunakan dalam penelitian ini disterilkan terlebih dahulu.Alat-alat gelas disterilkan dalam oven pada suhu $170^{\circ} \mathrm{C}$ selama \pm 1 jam (sterilisasi kering). Media disterilkandalamotoklafpadasuhu $\quad 121^{\circ} \mathrm{C}$ selama 15 menit (sterilisasibasah).

\section{Isolasi jamur endofit}

Isolasi jamur endofit dilakukan dengan cara akar bakau jenis Rhizophora apiculatayang diambil dari pesisir pantai Tasik Ria dipotong dan ditanam langsung pada media PDA (potato dextrose agar) setelah dilakukan perendaman pada etanol $70 \%$ selama 30 detik. Potongan akar ditanam pada cawan petri. Tiap cawan petri berisi 4 potongan sampel. Kemudian cawan petri ditutup (sealing) dan diinkubasi pada suhu kamar selama 1-2 X 24 jam.

\section{Pemurnian jamur endofit}

Miselia jamur yang telah tumbuh pada media PDA kemudian secara bertahap dimurnikan satu-persatu dengan menggunakan kawat ose steril dan dipindahkan ke media PDA steril pada cawan petri lainnya. Pemurnian ini bertujuan untuk memisahkan koloni endofit dengan morfologi yang berbeda untuk dijadikan isolat tersendiri. 


\section{Penyiapan bakteri uji}

Sebanyak 37 gr BHI (Brain Heart Infusion) dilarutkan dalam 1liter akuades, kemudian disterilkan dengan otoklaf pada suhu $121^{0} \mathrm{C}$ selama 15 menit. Media selanjutnya dituang kedalam tabung reaksi sebanyak $5 \mathrm{ml}$ untuk selanjutnya digunakan sebagai media suspensi bakteri. Koloni bakteri diambil menggunakan kawat ose steril dan dimasukkan kedalam media BHI. Kekeruhan bakteri distandarisasi dengan Larutan Kekeruhan Mc.Farland. Suspensi bakteri kemudian digoreskan dengan menggunakan lidi kapas steril di atas permukaan media kombinasi. Media kombinasi dibuat dengan mencampur media PDA dengan NA, kemudian media ditaruh kedalam cawan petri dan disterilisasi menggunakan otoklaf.

\section{Uji kemampuan hambat jamur endofit}

Penanaman jamur dilakukan masingmasing 5 potongan sampel jamur pada cawan petri yang berisi media kombinasi (PDA + NA) dengan jarak yang sama. Ciprofloxacin sebagai kontrol positif dilarutkan sebanyak 2mg/ml. Kertas saring yang telah dipotong hingga ukuran kecil kemudian dicelupkan kedalam larutan kontrol dan diletakkan ditengahtengah media yang telah diletakkan jamur endofit. Selanjutnya diinkubasi pada suhu kamar selama 1 X 24 jam. Kemudian zona hambat dari masing-masing jamur diamati dan diukur.

\section{Pengukuran zona hambat}

Pengukuran zona hambat dilakukan dengan menggunakan kaliper dengan cara membalik cawan petri dan mengukur diameter daerah jernih (clear zone) yang terbentuk.

\section{HASIL DAN PEMBAHASAN}

Dua jenis isolat jamur endofit hitam dan putih berhasil diisolasi dari akar bakau jenis Rhizophora apiculata yang dikultur pada media Potato Dekstrose Agar (PDA). Dalam penelitian yang dilakukan oleh Noverita, jamur yang diisolasi dari daun lebih banyak dari pada yang diisolasi dari rimpang. Hal ini diduga karena lebih mudah mendapatkan nutrisi dari daun dibandingkan dari rimpang. ${ }^{5,6}$ Jamur endofit yang diisolasi dari akar bakau Rhizophora apiculata dapat dilihat pada gambar dibawah ini:

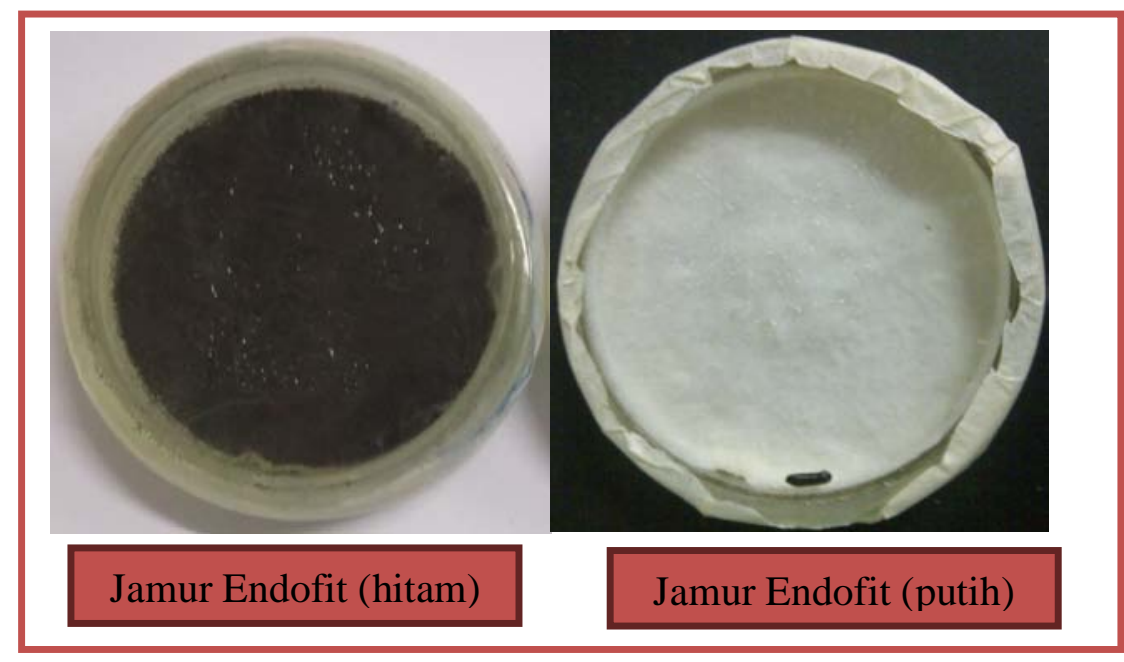

Gambar 1. Jamur Endofit 
Terlihat perbandingan rata-rata zona hambat yang oleh jamur hitam dan jamur putih pada kedua jenis bakteri uji. Strain jamur hitam menunjukkan aktivitas penghambatan yang lebih kuat dibandingkan dengan strain jamur putih. Adanya efek penghambatan terhadap kedua jenis bakteri uji, yakni Staphylococcus aureus dan Escherichiae coli membuktikan bahwa jamur endofit yang dihasilkan memiliki daya hambat pertumbuhan bakteri dengan spektrum yang luas, yaitu dapat menghambat pertumbuhan bakteri Gram positif dan Gram negatif yang telah diwakilkan oleh kedua bakteri uji tersebut.Hasil pengujian daya antibakteri 2 isolat jamur endofit yang diisolasi dari akar bakau Rhizophora apiculata terhadap bakteri Staphylococcus aureus dan Escherichiae coli ditunjukkan pada tabel dibawah ini :

Tabel 1. Hasil pengujian daya hambat jamur endofit akar bakau Rhizophora apiculata terhadap bakteri Staphylococcus aureus dan Escherichiae coli.

\begin{tabular}{|c|c|c|c|c|c|}
\hline \multirow[t]{2}{*}{ NO } & \multirow{2}{*}{$\begin{array}{l}\text { Diameter } \\
\text { jamur } \\
(\mathrm{cm})\end{array}$} & \multicolumn{2}{|c|}{$\begin{array}{l}\text { Diameter }(\mathrm{cm}) / \text { Luas zona hambat } \\
\left(\mathrm{cm}^{2}\right) \text { pada Staphylococcus aureus }\end{array}$} & \multicolumn{2}{|c|}{$\begin{array}{l}\text { Diameter }(\mathrm{cm}) / \text { Luas zona hambat } \\
\left(\mathrm{cm}^{2}\right) \text { pada Escherichiae coli }\end{array}$} \\
\hline & & Hitam & Putih & Hitam & Putih \\
\hline 1 & 1 & $2,20 / 3,01$ & $2,00 / 2,35$ & $2,30 / 3,36$ & $2,50 / 4,12$ \\
\hline 2 & 1 & $2,00 / 2,35$ & $1,80 / 1,75$ & $2,40 / 3,73$ & $2,10 / 2,67$ \\
\hline 3 & 1 & $2,10 / 2,67$ & $1,90 / 2,04$ & $2,40 / 3,73$ & $2,10 / 2,67$ \\
\hline 4 & 1 & $2,00 / 2,35$ & $1,90 / 2,04$ & 2,30/3,36 & $2,40 / 3,73$ \\
\hline 5 & 1 & $2,00 / 2,35$ & 1,80/1,75 & $2,30 / 3,36$ & $2,20 / 3,01$ \\
\hline Rerata & 1 & $2,06 / 2,54$ & 1,88/1,98 & $2,34 / 3,50$ & $2,26 / 3,24$ \\
\hline $\begin{array}{c}\text { Simpang } \\
\text { Baku }\end{array}$ & $\mathbf{0}$ & $0,08 / 0,33$ & $0,08 / 0,24$ & $0,05 / 0,20$ & $0,18 / 0,65$ \\
\hline Kontrol (+) & & 2,00 & 2,00 & 1,70 & 1,70 \\
\hline
\end{tabular}






Gambar 2. Grafik perbandingan rata-rata diameter zona hambat

Perbandingan rata-rata zona hambat oleh jamur endofit ditunjukkan pada gambar 2. Terlihat kontrol positif ciprofloxacin juga memberikan efek daya hambat terhadap kedua jenis bakteri uji. Hal ini sesuai dengan kemampuan kerjanya untuk menghambat pertumbuhan bakteri dan spektrumnya yang luas untuk bakteri Gram positif dan Negatif. ${ }^{7}$ Walaupun demikian, daya hambat oleh jamur endofit terlihat lebih besar dibandingkan dengan daya hambat oleh kontrol positif ciprofloxacin. Zona hambat yang dihasilkan oleh jamur endofit terlihat lebih menonjol dibandingkan dengan yang dihasilkan oleh kontrol positif. Penelitian sebelumnya oleh Noverita dan Ernawati tentang isolasi dan uji aktivitas antibakteri jamur endofit terhadap bakteri uji yang sama, yaitu Staphylococcus aureus dan Escherichiae coli menunjukkan hasil yang serupa, yaitu jamur endofit yang dihasilkan dari daun dan rimpang tumbuhan memberikan efek daya hambat kepada kedua jenis bakteri uji tersebut. Selain itu, hasil pengukuran zona hambat yang terbentuk oleh jamur endofit lebih besar dibandingan kontrol positif ampisilin yang digunakan pada penelitian tersebut.,
Dengan demikian dapat dikatakan bahwa jamur endofit memiliki daya hambat terhadap pertumbuhan kedua jenis bakteri yang di ujikan pada penelitian ini. Dengan kata lain, isolat jamur endofit yang diisolasi dari akar bakau Rhizophora apiculata memiliki daya antibakteri yang signifikan dan bersifat broad spectrum. Data ini dapat dijadikan bahan acuan dalam penelitian selanjutnya untuk mendapatkan senyawa antibiotika yang baru.

\section{KESIMPULAN DAN SARAN}

Berdasarkan hasil penelitian yang telah dilakukan maka dapat diambil suatu kesimpulan yaitu jamur endofit yang diisolasi dari akar bakau Rhizophora apiculata mampu menghambat pertumbuhan bakteri Staphylococcus aureus dan Escherichiae coli.

Dari hasil penelitian perlu diajukan beberapa saran sebagai berikut :

1. Perlu diadakan penelitian lanjutan untuk mengetahui jenis dari jamur endofit yang dapat menghambat pertumbuhan bakteri.

2. Perlu diadakan penelitian lebih lanjut untuk mengetahui bahan aktif yang terkandung dalam jamur endofit 
3. Perlu diadakan penelitian lebih lanjut mengenai daya hambat pertumbuhan bakteri oleh jamur endofit terhadap bakteri patogen lainnya.

\section{UCAPAN TERIMA KASIH}

Ucapan terima kasih disampaikan kepada Widdhi Bodhi, SSi, M.Kes, Apt, DR. dr. Billy J Kepel, M.Med, Sc dan semua pihak yang baik secara langsung maupun tidak langsung telah menumbuhkan ide atau gagasan dalam pemikiran penulis sehingga dapat menyelesaikan skripsi ini.

\section{DAFTAR PUSTAKA}

1. Strobel GA. Natural products fromendophytic microorganism. Journal ofNatural Products 2004 ; 67:257-68

2. Anonymous. Artikel Tentang Ekosistem Mangrove. Available from http://lembarindonesia.wordpress.co $\underline{\mathrm{m} / 2008 / 07 / 14 / \text { ekosistem-mangrove/ }}$

3. Gillespie,H. Staphylococcus. Astikawati R, Editor. At a Glance Mikrobiologi Medis dan Infeksi. 3rd ed. Jakarta : Penerbit Erlangga ; 2008. h.32-3.

4. Gillespie,H. Patogenisitas Bakteri Gram Negatif Enterik. Astikawati R, Editor. At a Glance Mikrobiologi Medis dan Infeksi. 3rd ed. Jakarta : Penerbit Erlangga ; 2008. h.50-1

5. Noverita. Isolasi dan Uji Aktivitas Antibakteri Jamur Endofit Dari Daun dan Rimpang Zingiber ottensii Val. Jurnal Farmasi Indonesia. 4 : 171-76

6. Sinaga E. Daya Antibakteri Jamur Endofit Yang Diisolasi Dari Daun dan Rimpang Lengkuas (Alpinia galanga Sw.). Jurnal Farmasi Indonesia. $4: 171-76$
7. Setiabudy R. Golongan Kuinolon dan Fluorokuinolon. Gunawan S G, Editor. At Farmakologi dan Terapi. 5th ed. Jakarta : Balai Penerbit FKUI ; 2008. H.718-9 